\title{
Mechanism of cell death induced by spermine and amine oxidase in mouse melanoma cells
}

\author{
DIANA A. AVERILL-BATES ${ }^{1}$, QIXIANG KE ${ }^{1}$, ANDRÉ TANEL ${ }^{1}$, JULIE ROY ${ }^{1}$, \\ GUY FORTIER $^{2}$ and ENZO AGOSTINELLI ${ }^{3}$
}

\begin{abstract}
${ }^{1}$ Département des Sciences Biologiques, ${ }^{2}$ Département de chimie, Université du Québec à Montréal, C.P. 8888, Succursale Centre-Ville, Montréal, Québec, H3C 3P8, Canada; ${ }^{3}$ Department of Biochemical Sciences 'A Rossi Fanelli', University of Rome 'La Sapienza' and CNR, Biology and Molecular Pathology Institutes, Piazzale Aldo Moro 5, I-00185 Rome, Italy
\end{abstract}

Received July 12, 2007; Accepted August 20, 2007

\begin{abstract}
Polyamines such as spermine, spermidine and putrescine are necessary for cell proliferation and are detected at higher concentrations in most tumor tissues, compared to normal tissues. The amine oxidase enzymes can generate cytotoxic products such as hydrogen peroxide and aldehydes from these polyamines. This study investigates the mechanisms of cell death in B16-F0 mouse melanoma tumor cells exposed to bovine serum amine oxidase and exogenous spermine. The bovine serum amine oxidase/spermine enzymatic system induced inhibition of cell proliferation in B16-F0 melanoma cells and cell death by both apoptotic and necrotic processes. Bovine serum amine oxidase or spermine, alone, did not induce cytotoxicity or cell death by apoptosis, indicating that the enzymatic reaction products were responsible. Catalase and NAD-dependent aldehyde dehydrogenase, inhibitors of hydrogen peroxide and aldehydes, respectively, decreased cell death by apoptosis and necrosis. This further confirms that the cytotoxic products are responsible for causing cell death. Use of inhibitors of different caspases showed that melanoma cells were sensitive to processes involving caspase-3 and -9, but were insensitive to caspase- 6 . Bovine serum amine oxidase in the presence of spermine could be useful as a promising new tool for anticancer treatment by the selective generation of toxic compounds from polyamines in tumors.
\end{abstract}

Correspondence to: Dr Diana A. Averill-Bates, Département des Sciences Biologiques, Université du Québec à Montréal, C.P. 8888, Succursale Centre-Ville, Montréal, Québec, H3C 3P8, Canada E-mail: averill.diana@uqam.ca

Abbreviations: ALDH, aldehyde dehydrogenase; BSAO, bovine serum amine oxidase; CHO, Chinese hamster ovary; FBS, fetal bovine serum; GPx, glutathione peroxidase; GST, glutathione Stransferase; ODC, ornithine decarboxylase; MAPK, mitogen-activated protein kinases; MDR, multidrug resistance; PEG, polyethylene glycol; PS, phosphatidylserine; PI, propidium iodide; SEM, standard error of mean

Key words: bovine serum amine oxidase, spermine, apoptosis, caspase, aldehyde dehydrogenase, catalase

\section{Introduction}

The polyamines spermine, spermidine and putrescine are ubiquitous cell components, which are essential for cell proliferation and differentiation (1). If they accumulate excessively within cells, either due to very high extracellular amounts or deregulation of the systems that control polyamine homeostasis, they can induce toxic effects (2). These molecules are substrates of a family of enzymes, the amine oxidases, that includes copper containing amine oxidases isolated from serum (3). These enzymes are important because they contribute to regulating the levels of monoamines and polyamines (4). Amine oxidases catalyze the oxidative deamination of polyamines to generate the reaction products hydrogen peroxide and aldehyde(s) (3). Such toxic products are able to induce stress-activated signal transduction pathways, leading to cell death, necrosis or apoptosis, in several cultured tumor cell lines (5-7). The diversity between normal and tumor cells is related to polyamine content and metabolism. Polyamine concentrations are high in growing tissues such as tumors of, for example, the breast and colon (8), compared to normal tissues. These increased levels can be explained by enhanced putrescine synthesis by ornithine decarboxylase (ODC) and increased uptake of polyamines (9). It was reported that depletion of polyamines led to the inhibition of tumor growth (4).

During the past decades, considerable research has been devoted to the discovery of new and more effective agents for clinical antitumor therapy, involving the polyamine pathway $(4,10-14)$. This research explores the possibility of using purified bovine serum amine oxidase (BSAO), in the presence of exogenous spermine or endogenous polyamines, to induce cytotoxicity, after injection of the enzyme into the tumor (15). BSAO (EC 1.4.3.6) is a copper-containing glycoprotein weighing $170 \mathrm{kDa}$, which oxidatively deaminates the primary amino groups of polyamines, such as spermine and spermidine. The reaction involves dioxygen and water as substrates (16). The products are $\mathrm{H}_{2} \mathrm{O}_{2}$, aldehydes and ammonia $(16,17)$. In the case of spermine, the monoaldehyde, the unstable dialdehyde intermediate [N,N'-bis(3-propionaldehyde)-1,4-butanediamine], and a further breakdown product, likely to be acrolein, may be formed $(18,19)$. Taking into account the higher levels of 
polyamines in tumor tissues $(9,16)$, BSAO could be delivered to tumors and used to generate cytotoxic molecules from spermine and spermidine in situ, leading to a promising new treatment for the destruction of tumors by enzymotherapy.

It was previously reported that purified BSAO and spermine, in causing cytotoxicity, can induce inhibition of cell proliferation and severe glutathione depletion in Chinese hamster ovary $(\mathrm{CHO})$ cells $(20,21)$. The cytotoxic effect induced by spermine and BSAO appeared to be mediated by the oxidation products, $\mathrm{H}_{2} \mathrm{O}_{2}$ and aminodialdehyde or acrolein. In our experimental conditions, $\mathrm{H}_{2} \mathrm{O}_{2}$ was the main factor causing cytotoxicity in cells, since the addition of catalase provided almost complete protection against cell killing. The residual cytotoxicity was attributed to the other reaction product, aminodialdehyde or acrolein. We previously demonstrated that the simultaneous presence of exogenous enzymes, catalase and NAD-dependent aldehyde dehydrogenase (ALDH), completely inhibited cytotoxicity $(6,22)$.

The development of multidrug-resistant (MDR) tumor cells, following exposure to cytotoxic drugs, is a major obstacle of conventional anticancer chemotherapy. Considering previous observations in P-glycoprotein overexpressing MDR CHO cells (23) and human cancer cells $(6,7,24,25)$, our results demonstrate that MDR cells are significantly more sensitive than the corresponding wild-type (WT) cells to $\mathrm{H}_{2} \mathrm{O}_{2}$ and aldehyde(s), the products of BSAO-catalyzed oxidation of spermine, suggesting a possible new strategy against MDR tumors. However, the mechanisms by which BSAO causes cell death in the presence of spermine are not entirely understood.

Physiologically, apoptosis is an integral part of embryonic development and the regulation of organ homeostasis. There are two main processes by which cells die: apoptosis or necrosis (26). Apoptosis is a highly regulated process involving numerous genes and proteins. Apoptotic mechanisms are also exploited for tumour therapy (2). An early morphological event in apoptosis is the loss of plasma membrane asymmetry, resulting in exposure of phosphatidylserine (PS) at the outer membrane leaflet (27). Caspases are proteolytic enzymes, which play an important role during apoptosis. They are divided into initiator (caspase-2, -8 and -9) and effector (caspase-3, -6 and -7) groups (28). The effector caspases cleave various protein substrates in the cell, leading to morphological and biochemical features characteristic of apoptosis. During later stages of apoptosis, internucleosomal degradation of DNA occurs, blebs appear on the cell membrane and the cell subsequently breaks down into apoptotic bodies, which are engulfed by phagocytic cells, thus avoiding inflammatory damage to surrounding tissues. However, severe changes of the mitochondrial structure, such as dilatation of the cristae and disruption of membranes with characteristic morphological changes, are common features of necrosis. Necrosis involves cellular swelling and leakage of cell contents into surrounding tissues, provoking inflammation and tissue damage.

Given that polyamine concentrations are high in growing tissues such as tumors $(9,16)$, this research explores the possibility of using purified BSAO to produce toxic products, which are able to induce a cytotoxic effect in mouse melanoma B16-F0 cells, human hepatocellular carcinoma HepG2 cells and human cervical carcinoma HeLa cells. This study investigates the mechanism(s) of cell death induced by spermine in the presence of purified BSAO in vitro. The objective is to determine whether, in our experimental conditions, mouse melanoma tumor cells die by apoptosis and/or necrosis, when exposed to $\mathrm{H}_{2} \mathrm{O}_{2}$ and aldehyde(s) formed by the BSAO/ spermine enzymatic system. We also examined whether inhibitors of the cytotoxic reaction products, catalase and/or ALDH, can inhibit cell death. Moreover, the involvement of different caspases in cell death caused by spermine and BSAO was evaluated using inhibitors of different caspases.

\section{Materials and methods}

Tissue culture. B16-F0 cells (ATCC \#CRL-6322) were grown in Dulbecco's modified Eagle's medium (Invitrogen Canada, Burlington, ON) containing 10\% fetal bovine serum (FBS) (Invitrogen Canada), $4 \mathrm{mM}$ L-glutamine, $4.5 \mathrm{~g} / 1$ glucose, $1.0 \mathrm{mM}$ sodium pyruvate and $1 \%$ penicillin $(50 \mathrm{U} / \mathrm{ml})$ streptomycin $(50 \mu \mathrm{g} / \mathrm{ml})$, supplemented with hydrocortisone $(1.4 \mu \mathrm{M})$, insulin $(10 \mu \mathrm{g} / \mathrm{ml})$, apo-transferrin $(10 \mu \mathrm{g} / \mathrm{ml})$ and epidermal growth factor (10 ng/ml) (Sigma Chemical Co, St. Louis, MO) (15). HepG2 cells (ATCC \#HB-8065) were cultured in minimum essential medium (Invitrogen Canada) with Earle's salts, $2 \mathrm{mM}$ L-glutamine, $1 \mathrm{mM}$ sodium pyruvate, $0.1 \mathrm{mM}$ non-essential amino acids and 10\% FBS. HeLa cells (ATCC \#CCL-2) were cultured in Dulbecco's modified Eagle's medium, $10 \%$ FBS, non-essential amino acids $(0.1 \mathrm{mM})$ and antibiotics. Tumor cells were grown to near confluence in a humidified atmosphere of $5 \% \mathrm{CO}_{2}$ in a water-jacketed incubator at $37^{\circ} \mathrm{C}$ and were then incubated for $24 \mathrm{~h}$ with fresh culture medium (15). Confluent cells were harvested using $0.25 \%(\mathrm{w} / \mathrm{v})$ trypsin- $0.02 \%(\mathrm{w} / \mathrm{v})$ EDTA solution, centrifuged (1000 x g, $3 \mathrm{~min}$ ) and resuspended in PBS containing $1 \%$ BSA and $10 \mathrm{mM}$ glucose for experimental studies.

Purification of BSAO. Bovine blood was withdrawn at a slaughterhouse and mixed with $3.8 \%$ sodium citrate solution (an anticoagulant) and then treated according to Turini et al (29) to purify the enzyme amine oxidase. The following modifications were made to the method: a) a CM-Cellulose column, equilibrated with phosphate buffer $(0.01 \mathrm{M})$ at $\mathrm{pH} 5.8$, to remove haemoglobin, followed by b) an AE-Agarose column, in phosphate buffer $(0.01 \mathrm{M})$ at $\mathrm{pH} 7.2$ to eliminate ceruloplasmin. Finally, two ionic exchange chromatographies were performed using a Q-Sepharose column, in phosphate buffer $(0.025 \mathrm{M})$ at $\mathrm{pH} 6.8$ and a Q-Sepharose column, in phosphate buffer $(0.02 \mathrm{M})$ at $\mathrm{pH} 8.0$, according to Janes et al (30). The enzyme was eluted and highly purified with an $\mathrm{NaCl}$ gradient. All purification steps were carried out in a cold room, at $4^{\circ} \mathrm{C}$.

Cytotoxicity assay. The colony survival assay measures the ability of cells to proliferate and form macroscopic colonies following exposure to cytotoxic treatments (31). Freshly harvested B16 and HepG2 cells $\left(10^{5} / \mathrm{ml}\right)$ were incubated with BSAO $(6.0 \mathrm{mU} / \mathrm{ml})$ and spermine $(0-50 \mu \mathrm{M})$, either with or without catalase $(300 \mathrm{U} / \mathrm{ml})$, for $1 \mathrm{~h}$ at $37^{\circ} \mathrm{C}$. The cells were then washed three times by centrifugation ( $1000 \mathrm{x} \mathrm{g}, 3 \mathrm{~min})$, and then diluted and plated in tissue culture dishes, which were incubated at $37^{\circ} \mathrm{C}$ in an atmosphere of $5 \% \mathrm{CO}_{2}$ for 12 days. Macroscopic colonies (>50 cells) were stained with 


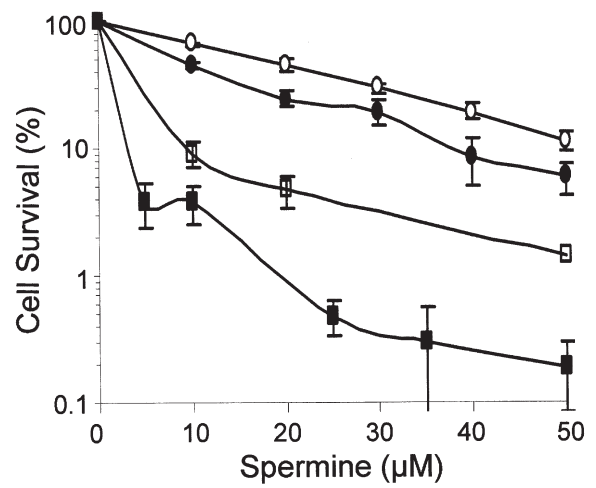

Figure 1. BSAO and spermine induced cytotoxicity in B16 melanoma and HepG2 liver cells: inhibition by catalase. (•) B16 and (ø) HepG2 cells $\left(10^{5} / \mathrm{ml}\right)$ were treated with BSAO $(6.0 \mathrm{mU} / \mathrm{ml})$ and different concentrations of spermine for $1 \mathrm{~h}$ at $37^{\circ} \mathrm{C}$. ( $\left.\circ\right) \mathrm{B} 16$ and $(\square) \mathrm{HepG} 2$ cells were exposed to BSAO and spermine for $1 \mathrm{~h}$ with catalase $(300 \mathrm{U} / \mathrm{ml})$. Means and SEM are from 3 separate experiments.

methylene blue. Percent cell survival was expressed as the mean number of colonies obtained relative to the mean number of colonies formed in the untreated control (31).

Morphological analysis of apoptosis and necrosis. Near confluent B16 cells were exposed to BSAO $(6.0 \mathrm{mU} / \mathrm{ml})$ and spermine $(0-200 \mu \mathrm{M})$, either alone, or with either ALDH (0.4 U/ml) (Roche Diagnostics GmbH Mannheim, Germany), or catalase (300 U/ml) (Sigma), catalase and ALDH together, or polyethylene glycol-catalase (PEG-catalase) $(300 \mathrm{U} / \mathrm{ml})$ (Sigma), in culture dishes for $3 \mathrm{~h}$ at $37^{\circ} \mathrm{C}$ in a water-jacketed incubator. Where appropriate, cells were pretreated for $1 \mathrm{~h}$ with different caspase inhibitors $(8 \mu \mathrm{M})$ (Calbiochem, San Diego, CA), washed to remove inhibitors and then incubated with BSAO $(6.0 \mathrm{mU} / \mathrm{ml})$ and spermine $(50 \mu \mathrm{M})$ for $3 \mathrm{~h}$. Dishes were then washed twice with PBS and Hoechst 33258 $(60 \mu \mathrm{g} / \mathrm{ml})$ was added for $15 \mathrm{~min}$ to stain apoptotic cells. Cells were washed and propidium iodide (PI) $(50 \mu \mathrm{g} / \mathrm{ml})$ was added to stain necrotic cells. Images obtained by fluorescence microscopy (Carl Zeiss Canada Ltd, Montreal, QC) were analysed by Northern Eclipse software and pictures were taken by digital camera (camera 3CCD, Sony DXC-950P, Empix Imaging Inc, Mississauga, ON) (32). Cells were classified using the following criteria: a) live cells, normal nuclei, pale blue chromatin with organized structure; b) membrane-intact apoptotic cells, bright blue condensed or fragmented chromatin; and c) necrotic cells, red, enlarged nuclei with smooth normal structure (33). The fractions of apoptotic and necrotic cells were determined relative to total cells (obtained using bright field illumination). A minimum of 200 cells were counted per dish.

Analysis of apoptosis by annexin V-FITC staining. Externalized phosphatidylserine (PS) on the outer surface of the cytoplasmic membrane becomes labelled by fluorescein (FITC)labelled annexin $\mathrm{V}$, which has a high affinity for PS-containing phospholipid bilayers (27). To analyze apoptotic cell death by flow cytometry, B16 melanoma cells $\left(1 \times 10^{6} / \mathrm{ml}\right)$ were incubated for $1 \mathrm{~h}$ with acrolein $(50 \mu \mathrm{M})$ or with $\mathrm{H}_{2} \mathrm{O}_{2}(50 \mu \mathrm{M})$, or for $2 \mathrm{~h}$ with $\mathrm{BSAO}(6.0 \mathrm{mU} / \mathrm{ml})$ and spermine $(50 \mu \mathrm{M})$,

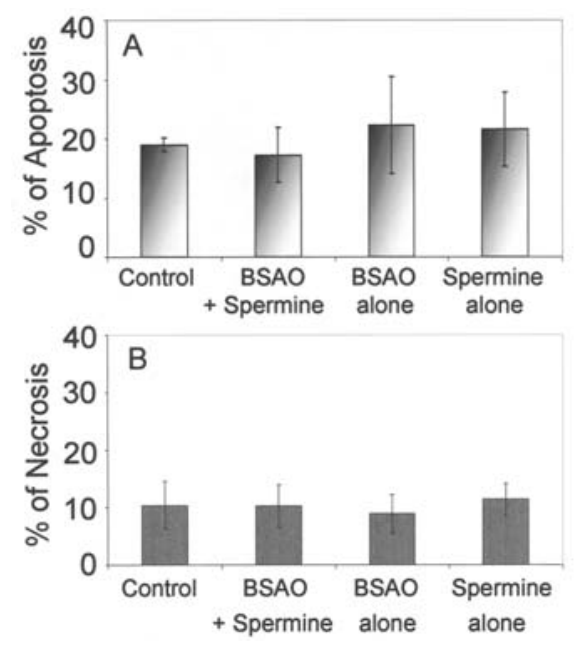

Figure 2. Lack of toxicity of BSAO and spermine in HeLa cells. HeLa cells were exposed to 1 and $2 \mathrm{~h}$ (data not shown) of treatment with BSAO $(6 \mathrm{mU} /$ $\mathrm{ml})+$ spermine $(100 \mu \mathrm{M})$ together, BSAO alone, or spermine alone, relative to untreated controls. Cells were analysed for apoptosis (A) using Hoechst 33258, and necrosis with PI (B). Means and SEM are from 3 separate experiments.

either alone or together. Where appropriate, catalase $(300 \mathrm{U} / \mathrm{ml})$ and $\operatorname{ALDH}(0.4 \mathrm{U} / \mathrm{ml})$ were added to the cells, before exposure to BSAO and spermine. Cells were then washed twice with PBS and resuspended in $1 \mathrm{ml}$ of binding buffer $(10 \mathrm{mM}$ Hepes/NaOH, pH 7.5, $140 \mathrm{mM} \mathrm{NaCl}$, and $\left.2.5 \mathrm{mM} \mathrm{CaCl}_{2}\right)$. A volume of $500 \mu \mathrm{l}$ of cell suspension was incubated with $5 \mu 1$ of annexin V-FITC (BD Biosciences Canada, Mississauga, $\mathrm{ON}$ ) and $5 \mu \mathrm{l}$ of PI for $10 \mathrm{~min}$ at room temperature in the dark. Cells were then analysed by flow cytometry using a FACScan equipped with an argon laser emitting at $488 \mathrm{~nm}$ and analyzed using Lysis II software (Becton Dickinson, Oxford, UK) (15). Annexin V-FITC and PI fluorescence were detected on FL-1 and FL-3 detectors, respectively. Four populations of cells were analysed: live control cells in the lower-left quadrant (annexin $\mathrm{V}^{-} / \mathrm{PI}^{-}$); early-stage apoptotic cells in the lower-right quadrant (annexin $\mathrm{V}^{+} / \mathrm{PI}^{-}$); late-stage apoptotic cells in the upper-right quadrant (annexin $\mathrm{V}^{+} / \mathrm{PI}^{+}$); and necrotic cells in the upper-left quadrant (annexin $\mathrm{V}^{-} / \mathrm{PI}^{+}$). The results are reported as the fraction of total apoptotic cells (early- and late-stage apoptosis).

Caspase activity. The activity of caspases was measured according to Hampton and Orrenius (34), with minor modifications (32). Briefly, $3 \times 10^{5}$ cells $/ \mathrm{ml}$ were incubated with $\operatorname{BSAO}(6.0 \mathrm{mU} / \mathrm{ml})$ and spermine $(0-100 \mu \mathrm{M})$ at $37^{\circ} \mathrm{C}$, or with $\mathrm{H}_{2} \mathrm{O}_{2}(0-75 \mu \mathrm{M})$ or acrolein $(0-50 \mu \mathrm{M})$. Cells were then washed twice by centrifugation $(1000 \mathrm{x} \mathrm{g}, 3 \mathrm{~min})$ in cold $\mathrm{PBS}$ and resuspended in reaction buffer $[20 \mathrm{mM}$ piperazineN-N-bis-(2-ethanesulfonic acid), $100 \mathrm{mM} \mathrm{NaCl}, 10 \mathrm{mM}$ dithiothreitol, 1 mM EDTA, 0.1\% 3-(3-cholamidopropyldimethylammonio)-2-hydroxy-1-propane sulfonic acid and $10 \%$ sucrose, $\mathrm{pH} 7.2$ ]. Cells were lysed at $-20^{\circ} \mathrm{C}$ for $12 \mathrm{~min}$. The kinetic reaction was started after addition of the appropriate caspase substrate (final concentration of $50 \mu \mathrm{M}$ ) at $37^{\circ} \mathrm{C}$ using a Spectra Max Gemini spectrofluorometer (Molecular Devices, Sunnyvale, CA). For caspase-3, the peptide substrate DEVD-AMC (Ac-Asp-Glu-Val-Asp-AMC) was added to cell 

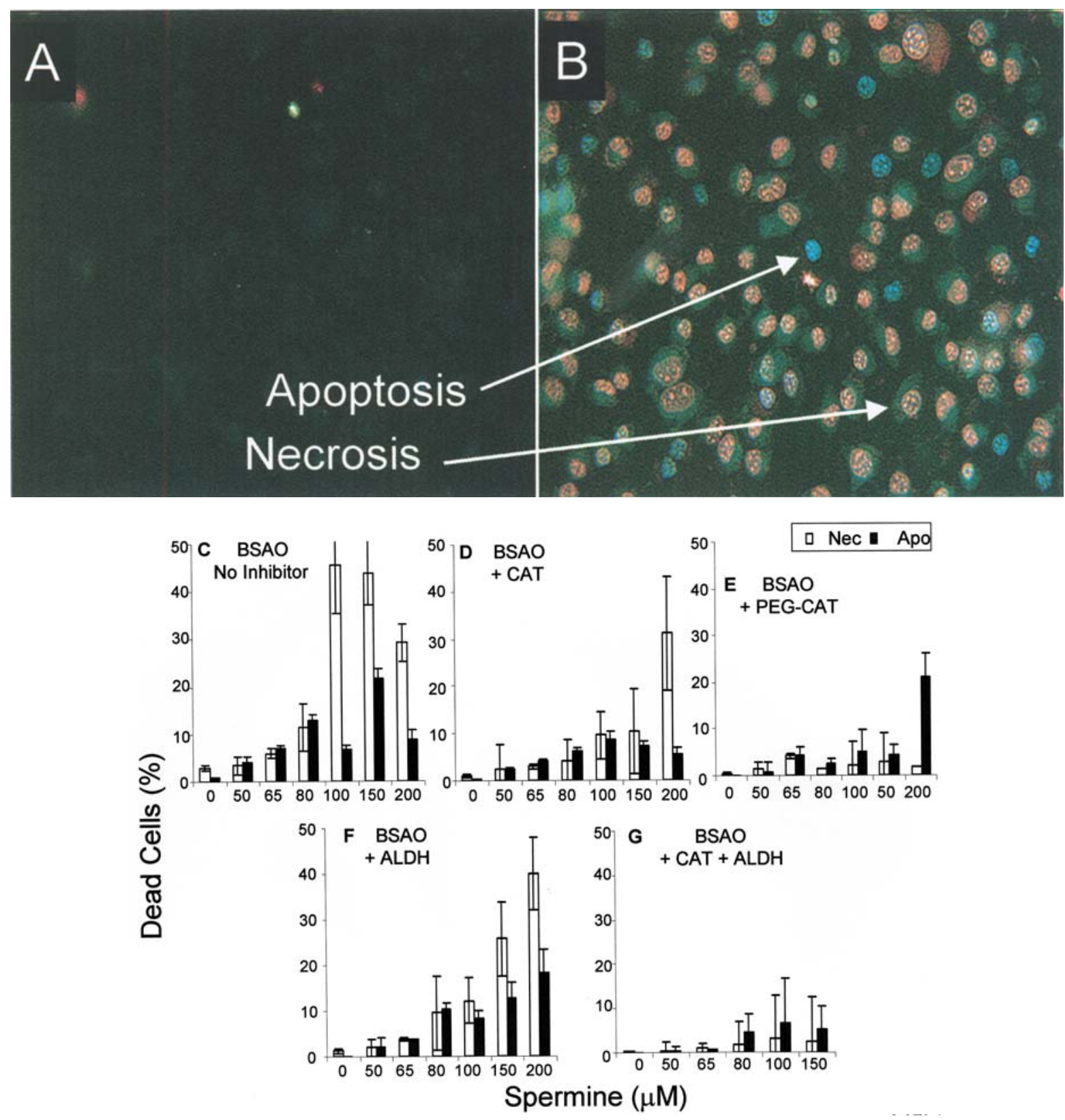

Figure 3. Inhibitors of $\mathrm{H}_{2} \mathrm{O}_{2}$ and aldehydes decreased apoptosis and necrosis induced by spermine and BSAO in B16 melanoma cells. B16 cells were treated with spermine $(150 \mu \mathrm{M})$ and BSAO $(6.0 \mathrm{mU} / \mathrm{ml})$ for $3 \mathrm{~h}(\mathrm{~B})$, relative to untreated control cells (A). Apoptotic cells (chromatin condensation) were stained with Hoechst 33258 and necrotic cells with PI. Magnification: x320. B16 cells were treated with spermine $(0-200 \mu \mathrm{M})$ and BSAO $(6.0 \mathrm{mU} / \mathrm{ml})$ for $3 \mathrm{~h}$, either with (C) no inhibitor, or with the inhibitors (D) catalase (300 U/ml), (E) PEG-catalase (300 U/ml) (pretreatment for $4 \mathrm{~h})$, (F) ALDH (0.4 U/ml), or (G) both catalase and ALDH. The fractions of ( $\square$ ) apoptotic and ( $\square$ ) necrotic cells are given relative to total cells. Means and SEM are from 3 separate experiments.

lysates and followed by kinetics for 30 min with excitation wavelength $(\lambda \mathrm{Ex})$ at $380 \mathrm{~nm}$ and emission wavelength $(\lambda \mathrm{Em})$ at $460 \mathrm{~nm}$. For caspase-6, the substrate was VEID-AMC (AcVal-Glu-IIe-Asp-AMC), for caspase-7, the substrate was MCA-VDQVDGWK(DNP)-NH 2 [MCA-Val-Asp-Gln-ValGly-Trp-Lys-(DNP)-NH $\mathrm{NH}_{2}$ ( $\left.\lambda \mathrm{Ex}, 325 \mathrm{~nm} ; \lambda \mathrm{Em}, 392 \mathrm{~nm}\right)$ and for caspase-9, the substrate was LEHD-AFC (Ac-Leu-GluHis-Asp-AFC) ( $\lambda$ Ex, $415 \mathrm{~nm} ; \lambda$ Em, $490 \mathrm{~nm})($ Calbiochem).

\section{Results}

Cytotoxicity of spermine and BSAO. Purified BSAO $(6 \mathrm{mU} / \mathrm{ml})$ and exogenous spermine $(5-50 \mu \mathrm{M})$ caused cytotoxicity (loss of cell proliferation) in mouse melanoma B16 cells and in human hepatocellular carcinoma HepG2 cells during $1 \mathrm{~h}$ at $37^{\circ} \mathrm{C}$ (Fig. 1). Human HepG2 cells were more sensitive to cytotoxicity of spermine and BSAO than mouse melanoma cells. BSAO and spermine $(50 \mu \mathrm{M})$ decreased the percentage of cell survival to $0.2 \%$ in HepG2 cells, relative to only $6 \%$ in melanoma cells. As individual agents, BSAO (4.1-12.2 mU/ml) and spermine $(0-500 \mu \mathrm{M})$ did not cause cytotoxicity in B16 and HepG2 cells (data not shown). Catalase partially inhibited cytotoxicity induced by spermine and BSAO in both cell types. The toxicity of BSAO and spermine was also investigated in human HeLa cells. However, there was no induction of cell death by either necrosis or apoptosis (Fig. 2A and B) following 1 -h or $2-\mathrm{h}$ exposures to BSAO $(6 \mathrm{mU} / \mathrm{ml})$ and spermine $(100 \mu \mathrm{M})$, compared to untreated controls. 


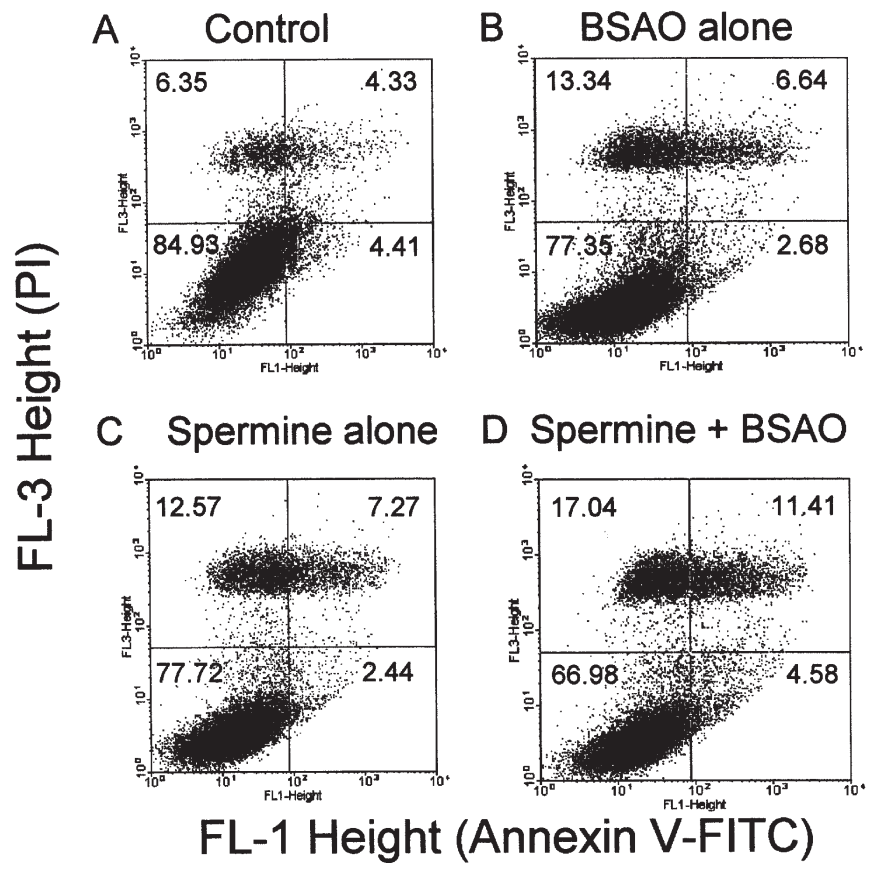

Figure 4. BSAO and spermine caused externalisation of PS (apoptosis) in B16 cells: protection by catalase and ALDH. Cells $(20,000)$ were analysed for apoptosis by flow cytometry with annexin V-FITC (FL-1 channel, x-axis) and PI (FL-3 channel, y-axis). B16 melanoma cells $\left(10^{6} / \mathrm{ml}\right)$ were either (A and F) left untreated, or treated with (B) BSAO $(6.0 \mathrm{mU} / \mathrm{ml})$ alone, (C) spermine $(50 \mu \mathrm{M})$ alone, or (D and $\mathrm{G}) \mathrm{BSAO}$ and spermine together, for $2 \mathrm{~h}$. B16 cells were incubated with BSAO and spermine in the presence of both catalase $(300 \mathrm{U} / \mathrm{ml})$ and ALDH $(0.4 \mathrm{U} / \mathrm{ml})(\mathrm{H})$. Representative FACScan diagrams are shown. Panels $\mathrm{E}$ and I represent means and SEM for percentage of annexin $\mathrm{V}^{+}$apoptotic cells from 2 series of 3 separate experiments.
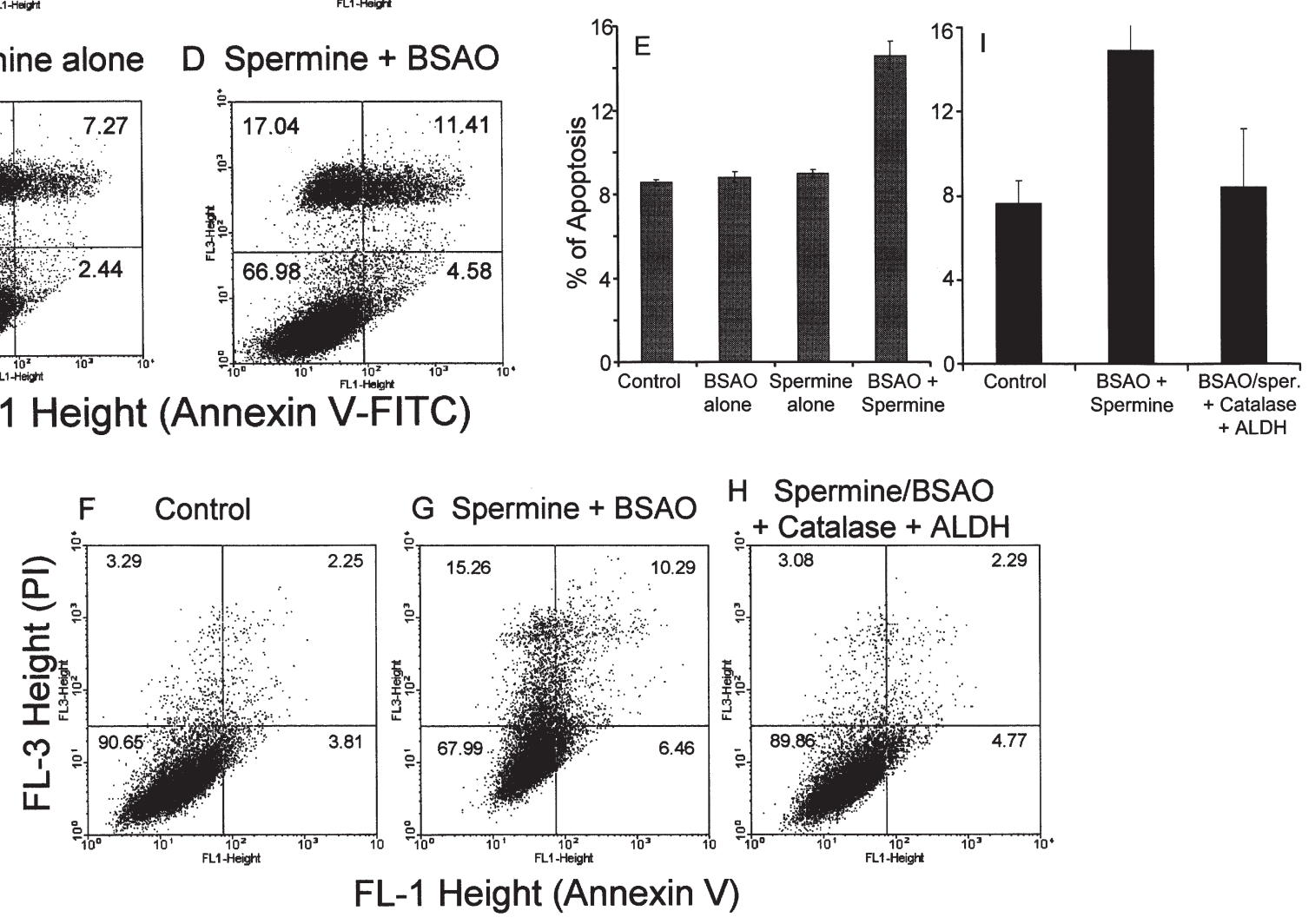

Morphological analysis of apoptosis and necrosis in B16 melanoma cells treated with spermine and BSAO: protective effects of catalase and aldehyde dehydrogenase. The type of cell death induced by BSAO and spermine was subsequently investigated in B16 melanoma cells. Induction of apoptosis was confirmed morphologically by the appearance of cells with condensation of nuclear chromatin (fragmented nuclei, blue fluorescence) (Fig. 3B). This is a well-characterized nuclear event which occurs at later stages in the apoptotic cascade. There was also a large induction of cellular necrosis (red fluorescence) (Fig. 3B). There were very few dead cells in untreated controls (Fig. 3A). Spermine alone and BSAO alone did not cause chromatin condensation or necrosis in our experimental conditions (data not shown), indicating that cell death was caused by the products of the enzymatic reaction. The numbers of apoptotic and necrotic cells in BSAO and spermine-treated melanoma cells were quantified from the microscope images (Fig. 3C). Both necrosis and apoptosis increased as the spermine concentration increased from 50 to $150 \mu \mathrm{M}$ (Fig. 3C). At higher concentrations of spermine (100-200 $\mu \mathrm{M})$, necrosis rather than apoptosis was the major cause of cell death, due to the larger amount of cytotoxic products formed in the presence of BSAO.
Subsequently, we determined whether the cytotoxic reaction products, $\mathrm{H}_{2} \mathrm{O}_{2}$ and aldehyde(s), were responsible for causing cell death. The ability of inhibitors of the cytotoxic products to decrease the level of apoptosis and necrosis generated by the enzymatic reaction of spermine and BSAO was evaluated (Fig. 3D-G). The inhibitors used were catalase (CAT) and PEG-catalase, which are both inhibitors of $\mathrm{H}_{2} \mathrm{O}_{2}$ (35) and ALDH, which inhibits aldehydes (including acrolein). Exogenously added catalase remains outside cells, whereas PEG-catalase allows the enzyme to enter cells (36) and to increase intracellular catalase activity (35). Exogenous catalase inhibited both necrosis and apoptosis caused by spermine and BSAO in melanoma cells (Fig. 3D). PEG-catalase (Fig. 3E) was a more effective inhibitor than exogenous catalase. This suggests that $\mathrm{H}_{2} \mathrm{O}_{2}$ exerts toxicity at both the intracellular and extracellular levels. However, BSAO remains outside cells and generates $\mathrm{H}_{2} \mathrm{O}_{2}$ and aldehyde(s) at the extracellular level. This indicates that $\mathrm{H}_{2} \mathrm{O}_{2}$ formed outside the cells is able to cross the membrane and to enter cells (6). ALDH also decreased both necrosis and apoptosis (Fig. 3F). Catalase had a greater inhibitory effect than ALDH. $\mathrm{H}_{2} \mathrm{O}_{2}$ was previously shown to be more cytotoxic to $\mathrm{CHO}$ cells at lower concentrations than aldehyde(s) (22). Also, aldehyde(s) became cytotoxic at later 

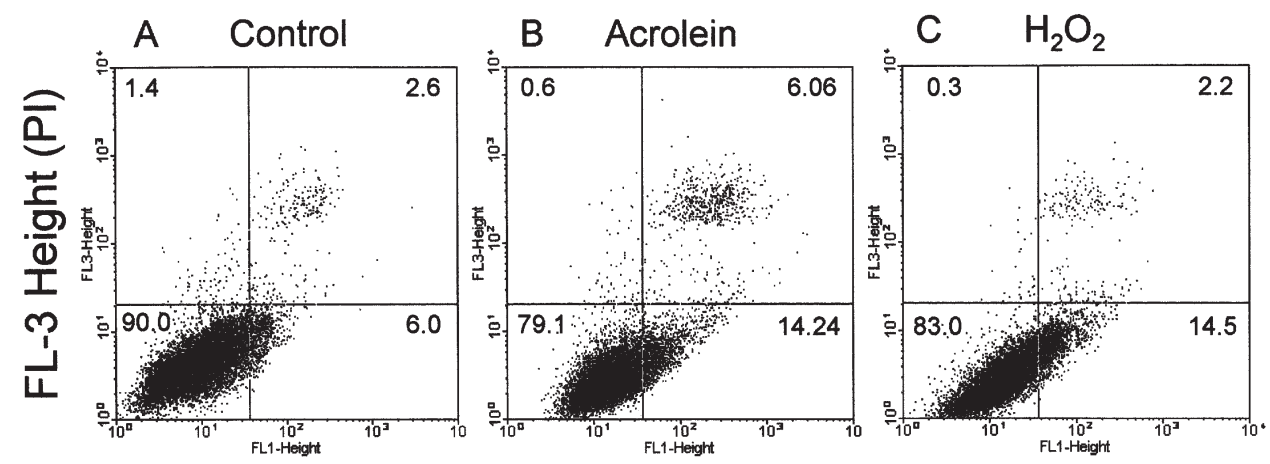

FL-1 Height (Annexin V-FITC)

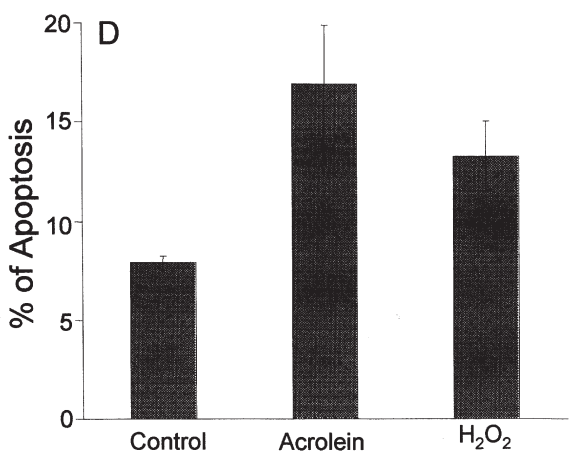

times during the reaction than $\mathrm{H}_{2} \mathrm{O}_{2}$. However, catalase and ALDH together (Fig. 3G) provided more effective inhibition of apoptosis and necrosis than either catalase or ALDH alone. These findings suggest that both toxic products $\left[\mathrm{H}_{2} \mathrm{O}_{2}\right.$ and aldehyde(s)] contribute to the induction of apoptosis and necrosis by BSAO and spermine in melanoma cells.

Analysis of apoptosis by annexin V binding to PS in B16 cells treated with spermine and BSAO: inhibition by catalase and aldehyde dehydrogenase. Apoptosis is characterized by a variety of morphological features. Changes in the plasma membrane are one of the earliest of these features. In apoptotic cells, the membrane phospholipid PS is translocated from the inner to the outer leaflet of the plasma membrane, thereby exposing PS to the external cellular environment (27). Annexin V, a phospholipid-binding protein with high affinity for PS, binds to apoptotic cells with externalized PS. Fig. 4 shows typical FACScan diagrams of annexin V-FITC/PI fluorescence obtained after treatment of B16 cells with BSAO $(6 \mathrm{mU} / \mathrm{ml})$ and spermine $(50 \mu \mathrm{M})$. When B16 cells were treated with both BSAO and spermine for $2 \mathrm{~h}$, there was a $60 \%$ increase in apoptotic cells (annexin $\mathrm{V}^{+}$) (Fig. 4D and E), compared to untreated controls (annexin $\mathrm{V}^{-} / \mathrm{PI}$ ) (Fig. 4A). BSAO (Fig. 4B) or spermine alone (Fig. 4C) did not cause apoptosis under these experimental conditions (Fig. 4E).

To confirm the role of the cytotoxic reaction products in causing externalisation of PS in the presence of spermine and BSAO, the ability of their inhibitors to decrease apoptosis was evaluated (Fig. 4F-I). The induction of annexin $\mathrm{V}$ membrane binding in spermine- and BSAO-treated B16 cells (Fig. 4G) was markedly inhibited in the presence of both catalase and ALDH (Fig. 4H and I), and returned to the control level (Fig. 4F and I). Subsequently, we evaluated whether $\mathrm{H}_{2} \mathrm{O}_{2}$
Figure 5. Acrolein and hydrogen peroxide cause annexin $\mathrm{V}$ binding (apoptosis) in melanoma cells. B16 cells $\left(10^{6} / \mathrm{ml}\right)$ were either (A) left untreated or treated with (B) $50 \mu \mathrm{M}$ acrolein or (C) $50 \mu \mathrm{M} \mathrm{H}_{2} \mathrm{O}_{2}$ for $1 \mathrm{~h}$. Cells $(20,000)$ were then stained with annexin V-FITC (FL-1 channel, X-axis) and PI (FL-3 channel, y-axis) and analysed by flow cytometry. Representative FACScan diagrams are shown. (D) Means \pm SEM are given for percentage of annexin $\mathrm{V}^{+}$apoptotic cells from 3 independent experiments.

and the aldehyde acrolein, two of the enzymatic oxidation products of spermine oxidation, could induce PS externalisation in melanoma cells (Fig. 5). Effectively, acrolein $(50 \mu \mathrm{M})$ (Fig. 5B and D) and $\mathrm{H}_{2} \mathrm{O}_{2}(50 \mu \mathrm{M})$ (Fig. 5C and D) were both able to increase annexin $\mathrm{V}$ binding to the plasma membrane, relative to untreated controls (Fig. 5A). Together, these findings further confirm that toxic products, such as aldehydes (e.g. acrolein) and $\mathrm{H}_{2} \mathrm{O}_{2}$, contribute to the induction of apoptosis by BSAO and spermine.

Role of caspase activation in the induction of apoptosis by $B S A O$ and spermine. The ability of purified BSAO and spermine to activate caspases has received little attention. Figs. 6 and 7 show the activities of caspase- $9,-3,-6$ and -7 in B16 melanoma cells exposed to BSAO $(6.0 \mathrm{mU} / \mathrm{ml})$ and spermine, or to their reaction products $\mathrm{H}_{2} \mathrm{O}_{2}$ and acrolein. The initiator caspase- 9 was activated by BSAO and spermine $(10-50 \mu \mathrm{M})$ in B16 cells after $30 \mathrm{~min}$ (Fig. 6A). Caspase-9 activity declined at higher concentrations of the polyamine (Fig. 6A). The toxic reaction products $\mathrm{H}_{2} \mathrm{O}_{2}$ (Fig. 6C) and acrolein (Fig. 6D) also activated caspase-9. BSAO $(6.0 \mathrm{mU} /$ $\mathrm{ml})$ alone and spermine $(5-200 \mu \mathrm{M})$ alone did not activate caspase-9 (Fig. 6B). This indicates that the reaction products generated by BSAO and spermine were responsible for activation of caspase- 9 .

The effector caspase-3 was also activated during 2-h exposures to BSAO and spermine (10-20 $\mu \mathrm{M})$ (Fig. 7A), and $\mathrm{H}_{2} \mathrm{O}_{2}$ (Fig. 7C). However, caspase- 3 activity was inhibited by acrolein in melanoma cells (Fig. 7D). BSAO $(6.0 \mathrm{mU} / \mathrm{ml})$ alone or spermine (5-200 $\mu \mathrm{M})$ alone had no effect on caspase-3 activity (Fig. 7B). However, the activities of the other effector caspases, caspase-6 (Fig. 7E) and caspase-7 (Fig. 7F) were inhibited by BSAO and spermine $(5-100 \mu \mathrm{M})$. These findings 

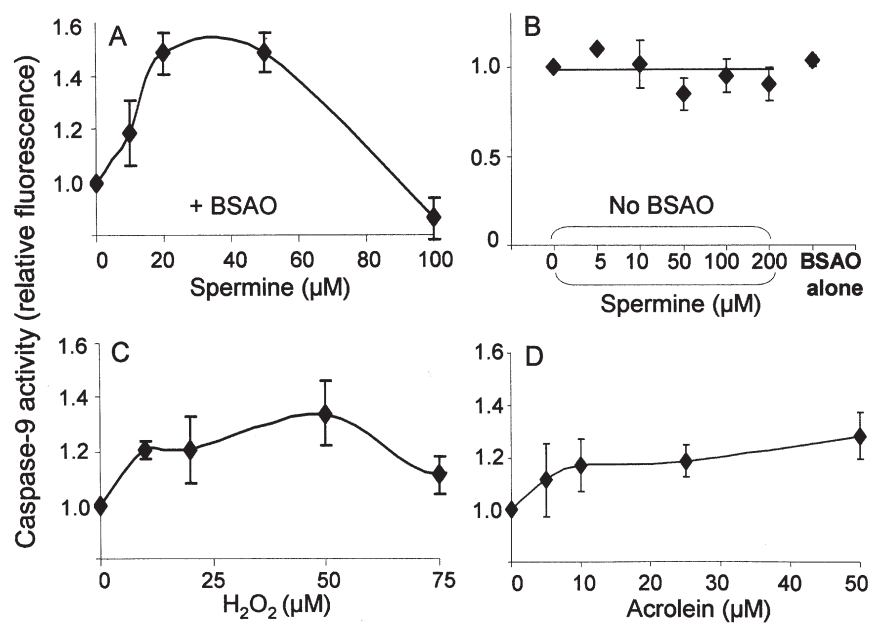

Figure 6. Activation of caspase-9 by spermine and BSAO in B16 cells. Melanoma cells were treated with (A) BSAO $(6.0 \mathrm{mU} / \mathrm{ml})$ and different concentrations of spermine $(0-100 \mu \mathrm{M})$, (B) spermine alone $(5-200 \mu \mathrm{M})$ or BSAO $(6.0 \mathrm{mU} / \mathrm{ml})$ alone, or $(\mathrm{C}) \mathrm{H}_{2} \mathrm{O}_{2}(0-75 \mu \mathrm{M})$, or (D) acrolein $(0-50 \mu \mathrm{M})$, for $30 \mathrm{~min}$. Caspase- 9 activity in treated cells was expressed relative to the untreated control (cells alone), designated as 1.0. Means and SEM are from 4-6 separate experiments.
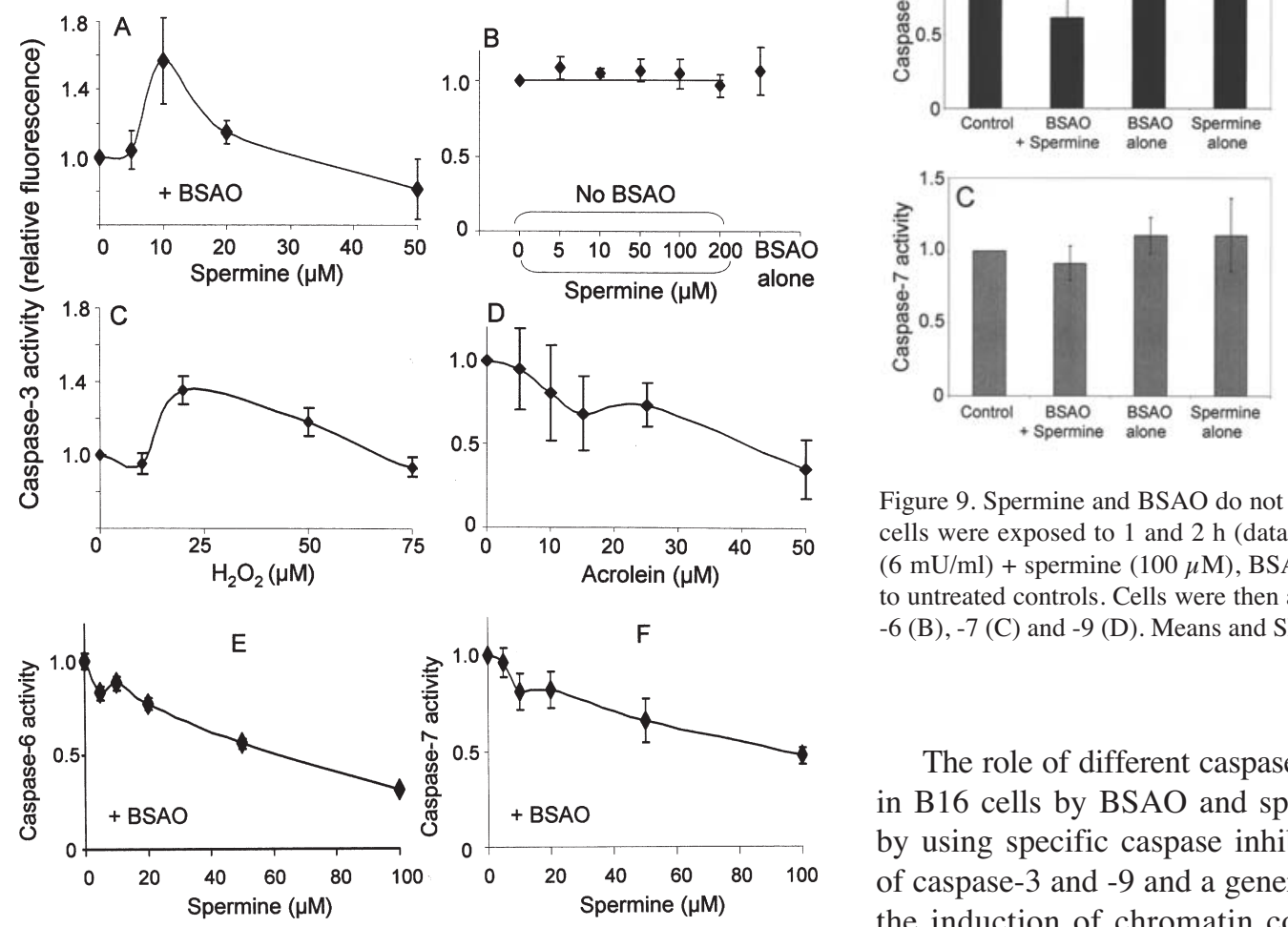

Figure 7. Activity of effector caspase-3, -6 and -7 in B16 cells exposed to BSAO and spermine. B16 cells were treated with (A) BSAO $(6.0 \mathrm{mU} / \mathrm{ml})$ and spermine $(0-50 \mu \mathrm{M})$, (B) spermine alone $(0-200 \mu \mathrm{M})$ or BSAO $(6.0 \mathrm{mU} /$ ml) alone, (C) $\mathrm{H}_{2} \mathrm{O}_{2}(0-75 \mu \mathrm{M})$, or (D) acrolein (0-50 $\left.\mu \mathrm{M}\right)$, for $2 \mathrm{~h}$. Caspase-3 activity in treated cells was expressed relative to the control (cells alone), designated as 1.0. Cells were treated with BSAO $(6.0 \mathrm{mU} / \mathrm{ml})$ and spermine $(0-100 \mu \mathrm{M})$ for $2 \mathrm{~h}$. (E) Caspase-6 and (F) caspase-7 activity was expressed relative to untreated controls. Means and SEM are from 4-6 separate experiments.

indicate that the cytotoxic products of the enzymatic reaction of BSAO and spermine induce apoptosis in B16 cells via activation of caspase- 9 and -3 .
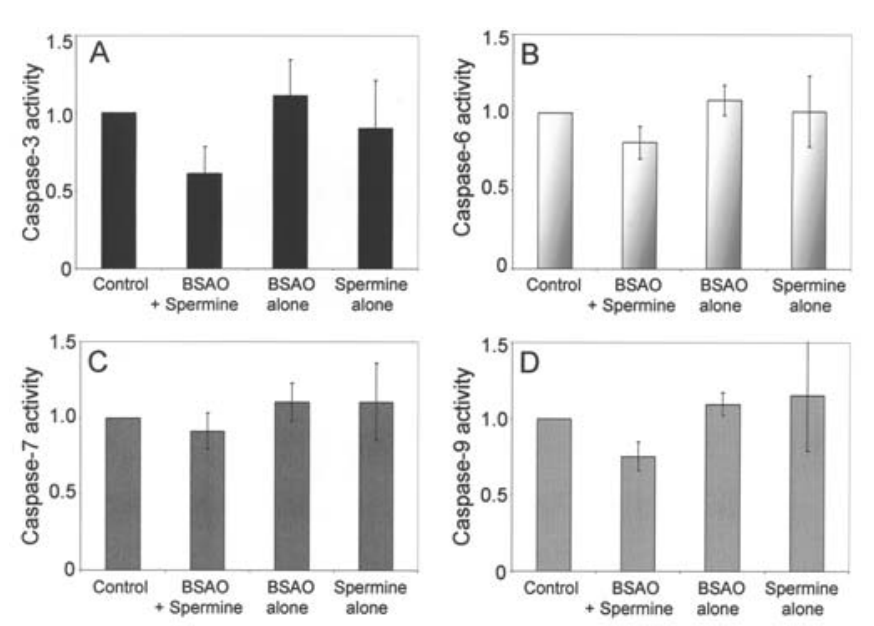

Figure 9. Spermine and BSAO do not activate caspases in HeLa cells. HeLa cells were exposed to 1 and $2 \mathrm{~h}$ (data not shown) of treatment with BSAO $(6 \mathrm{mU} / \mathrm{ml})+$ spermine $(100 \mu \mathrm{M}), \mathrm{BSAO}$ alone and spermine alone, relative to untreated controls. Cells were then analysed for activity of caspase-3 (A), -6 (B), -7 (C) and -9 (D). Means and SEM are from 3 separate experiments.

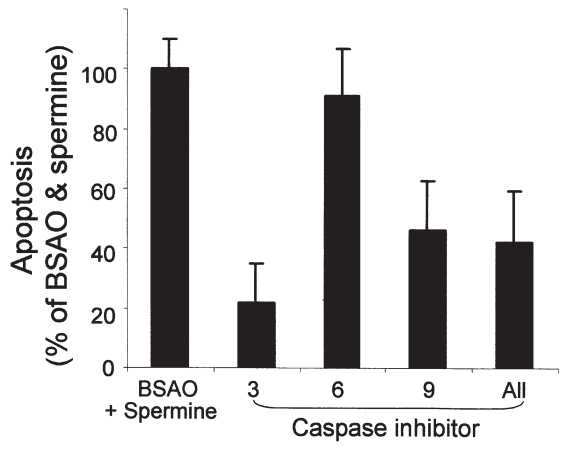

Figure 8. Inhibition of caspases decreases chromatin condensation induced by BSAO and spermine in melanoma cells. B16 cells were pretreated with specific inhibitors of caspase-3, -6 and -9 and a general caspase inhibitor $\operatorname{BSAO}(6.0 \mathrm{mU} / \mathrm{ml})$ for $3 \mathrm{~h}$. The fraction of apoptotic cells in the presence of caspase inhibitors is expressed relative to the fraction of apoptotic cells as $100 \%$. Means and SEM are from 3 separate experiments.

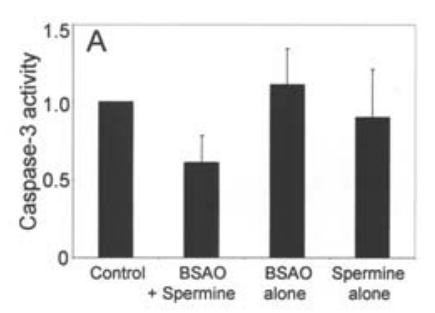

(B), 7 (C) and -9 (D). Means and SEM are from 3 separate experiments.

The role of different caspases in the induction of apoptosis in B16 cells by BSAO and spermine was further confirmed by using specific caspase inhibitors (Fig. 8) (37). Inhibitors of caspase- 3 and -9 and a general caspase inhibitor decreased the induction of chromatin condensation by spermine and BSAO in B16 cells (Fig. 8). An inhibitor of caspase-6 did not inhibit chromatin condensation, which is consistent with the lack of activation of caspase- 6 by BSAO and spermine. A specific inhibitor of caspase-7 is not commercially available.

Given that BSAO and spermine did not cause toxicity in HeLa cells, we investigated their effect on activity of caspases (Fig. 9). Interestingly, when HeLa cells were treated with BSAO $(6.0 \mathrm{mU} / \mathrm{ml})$ and spermine $(100 \mu \mathrm{M})$, there was a decrease in activity of caspase-3 (Fig. 9A), -6 (Fig. 9B) and -9 (Fig. 9D), relative to untreated controls. There was no clear effect on caspase-7 activity (Fig. 9C). The lack of caspase activation is consistent with the lack of induction of apoptosis by BSAO and spermine in HeLa cells (Fig. 2A). 


\section{Discussion}

Inhibition of tumor cell proliferation by enzymatic oxidation products of polyamines. The present findings show that BSAO and spermine caused cytotoxicity (loss of cell proliferation) in B16 melanoma and HepG2 liver carcinoma cells. The enzymatic reaction products, $\mathrm{H}_{2} \mathrm{O}_{2}$ and aldehyde(s), were both responsible for cytotoxicity, since catalase did not afford complete protection. Cytotoxicity induced by purified BSAO and spermine in CHO, human melanoma M14 and LoVo colon adenocarcinoma cells was also induced by both of the oxidation products, although it was mainly due to $\mathrm{H}_{2} \mathrm{O}_{2}$ $(6,7,22)$. However, spermine caused cytotoxicity in mouse mammary carcinoma FM3A cells, L1210 leukemia cells and NIH3T3 cells, in the presence of fetal calf serum (FCS) (19). In these studies, cytotoxicity was evaluated using the trypan blue exclusion assay, which is an indicator of damage to the membrane that corresponds to necrotic cell death. The cytotoxic effect of spermine was dependent on the presence of amino oxidase, which is known to be present in FCS. In these cell types, cell death was inhibited by ALDH, but not by catalase, and was mainly attributed to acrolein.

Induction of apoptosis by enzymatic oxidation products of polyamines. The first study to link polyamine oxidation to programmed cell death was reported during blastocyte development in murine embryos (38). Our findings show that purified BSAO and spermine induced cell death by apoptosis in B16 melanoma cells. The induction of apoptosis was revealed by condensation of nuclear chromatin, externalization of PS, activation of caspase- 3 and -9 and inhibition of apoptosis by caspase inhibitors. Induction of apoptosis was attributed to the toxic reaction products since catalase and ALDH, which are inhibitors of $\mathrm{H}_{2} \mathrm{O}_{2}$ and aldehydes, respectively, inhibited chromatin condensation and PS externalization induced by exposure to BSAO and spermine. Activation of caspase- 9 appeared to be mediated by both toxic reaction products. Caspase- 3 activation by BSAO and spermine, however, appeared to be mediated by $\mathrm{H}_{2} \mathrm{O}_{2}$, but not by acrolein. Inhibition of caspase- 3 activity by acrolein is consistent with another study in Chinese hamster ovary cells (32).

Our findings show that purified BSAO and spermine induced cell death in B16 melanoma cells by both apoptosis and necrosis, as well as cytotoxicity (loss of cell proliferation). Necrosis was confirmed by uptake of PI, which is an indicator of damage to the cell membrane. Apoptosis and necrosis constitute a two-stage continuum, where the same toxin or stimulus can induce, in a dose-related manner, either apoptosis or necrosis (39). For example, the toxic aldehyde acrolein was shown to induce cell death by both apoptosis and necrosis, with apoptosis occurring at lower doses and shorter exposure times, compared to necrosis (32).

However, studies in human colon adenocarcinoma WT and MDR LoVo cells did not reveal ultrastructural characteristics of apoptosis in the presence of BSAO and spermine $(6 \mu \mathrm{M})$, during $60 \mathrm{~min}$ of incubation, by transmission electron microscopy (6). In L1210 leukemia cells, none of the characteristic morphological features of apoptotic cell death [chromatin condensation, nuclear fragmentation, internucleosomal DNA cleavage, and poly(ADP-ribose) polymerase cleavage] were observed during cell death attributed to spermine oxidation mediated by serum containing a high level of amine oxidase (40). However, cell death was attributed to necrosis, which was preceded by a loss of phospholipid asymmetry, although this latter phenomenon is usually a feature of cell death by apoptosis. Moreover, inhibition of a wide spectrum of caspases did not prevent spermine and serum amine oxidase-dependent cell death in L1210 cells. Overall, it appears that the mode of cell death caused by oxidation products of spermine and BSAO appears to be cell type dependent.

Induction of apoptosis directly by polyamines. Polyamines are important regulators of cell growth and proliferation. They are involved in the progression of cells through the cell cycle $(41,42)$. Polyamine levels are altered during the cell cycle and can regulate important checkpoints of the cell cycle. As a consequence, depletion of polyamines results in growth arrest, mainly at the G1 phase (43). Polyamines are also involved in the Ras/mitogen-activated protein kinase (MAPK) signal transduction pathway, which is involved in cell proliferation, as well as stimulating the expression of the oncogenes c-myc, c-fos and c-jun $(44,45)$.

More recently, polyamines have also been implicated in events inherent to genetically programmed cell death $(46,47)$. However, the link between polyamines and apoptosis is complex and results are somewhat contradictory. Both upregulation and down-regulation of polyamine levels and ODC activity, a key step in polyamine biosynthesis, have been reported during apoptosis. Furthermore, depletion of polyamines can either protect or sensitize cells to apoptosis, depending on the cell type and the death-inducing signal (45). Elevation of polyamine concentrations may lead to apoptosis, independent of polyamine oxidase $(48,49)$, or to malignant transformation (46).

Polyamines appear to be involved at both the mitochondrial and post-mitochondrial levels of apoptosis. Spermine was shown to induce release of cytochrome $\mathrm{c}$ from mitochondria and to activate caspase- $3(48,49)$. On the other hand, polyamine depletion triggered the mitochondrial pathway of apoptosis by causing disruption of mitochondrial membrane potential leading to activation of caspase-3 (50).

Relevance of amine oxidase-mediated polyamine oxidation to anticancer treatment. Melanoma is an aggressive form of skin cancer, whose incidence is increasing steadily (51). Melanoma cells frequently exhibit inherent resistance to commonly used chemotherapeutic drugs. Despite a variety of anticancer strategies, there is a high level of treatment failure and the average patient survival rate is only 6 to 10 months. The present study shows that melanoma cells are sensitive to the toxic effects of oxidation products of BSAO and spermine. These findings are in agreement with recent results showing cytotoxic effects of spermine metabolites in human melanoma M14 cells (M14 WT) and their doxorubicin-resistant variant line (M14 ADR) (7). Therefore, a potential therapeutic strategy using BSAO and polyamines could be envisaged as a new targeted treatment in earlier stages of malignant melanoma, thus avoiding surgery.

The antitumor potential of BSAO was therefore evaluated in vivo, using a B16 mouse melanoma model in C57BL mice. 
BSAO, when directly injected into the solid tumors, was able to induce tumoricidal activity by converting endogenous polyamines to toxic products in situ (15). The enzyme was administered in its native form and also immobilized in a biocompatible polymer composed of bovine serum albumin and polyethylene glycol (PEG). The immobilized enzyme showed higher operational stability and functional activities, relative to its native form (52). When immobilized BSAO was injected into the tumor, there was a marked decrease (70\%) in tumor growth, compared to a lower decrease of $32 \%$ of tumor size when native BSAO was administered. The mechanisms of cell death were determined in vivo (15). When tumors were treated with immobilized BSAO, there was a high level of apoptotic cell death $(\sim 70 \%)$, compared to $<10 \%$ with the native enzyme. Native BSAO, probably due to a burst of cytotoxic products, induced a high level of necrosis ( $\sim 40 \%)$, compared to $<10 \%$ with immobilized BSAO. The advantage is that immobilized BSAO can act by allowing the slow release of cytotoxic products, which induces tumor cell death by apoptosis rather than necrosis, thus decreasing inflammatory damage to surrounding tissues.

From a therapeutic point of view, the improvement of the efficacy of in situ formation of cytotoxic polyamine metabolites is essential. This may be achieved by combinations of the treatment with cytotoxic drugs, or by heat. It was previously demonstrated that hyperthermia $\left(42^{\circ} \mathrm{C}\right)$ potentiates the cytotoxic effects of the oxidation products of spermine and BSAO in CHO, LoVo colon carcinoma cells and M14 human melanoma cells and in their MDR counterparts $(6,7,25,53)$. Hyperthermia is making considerable progress in the cancer clinic (54). Hyperthermia in combination with cytotoxic drugs, preferentially those with enhanced cytotoxicity at an elevated temperature (55), and the administration of drug combinations are clinically accepted methods. In 2002, it was reported that the combination of hyperthermia with either radiotherapy and/or chemotherapy led to improved clinical outcome in 18 randomized studies (reviewed in ref. 54). This was demonstrated for melanoma and cancers of the head and neck, breast, brain, rectum, cervix, oesophagus, lung and vulva/vagina. There have been many more promising results from clinical studies since then. Regional hyperthermia has the potential to increase cytotoxic effects of radiation or chemotherapeutic agents within the tumor mass, without increasing normal tissue toxicity. Hyperthermia is applied in cancer patients in the clinic by either localized heating of the tumor at temperatures such as $42-43^{\circ} \mathrm{C}$ for $1-2 \mathrm{~h}$, or by milder heating at $39.5-41^{\circ} \mathrm{C}$ for longer times $(6-24 \mathrm{~h})$. The latter, whole body hyperthermia is often used to treat carcinomas with distant metastases. In this kind of cancer, the cytotoxic effect of aldehydes could be effective. In fact, patients with inoperable carcinomas in terminal stages were treated with benzaldehyde with satisfactory results (56).

Currently, we are studying drug combinations with the aim of improving the induction of cell death by toxic polyamine metabolites. When combined with BSAO, pretreatment with the lysosomotropic drug, $\mathrm{N}^{1}, \mathrm{~N}^{4}$-bis(2,3-butadienyl)-1,4butanediamine dihydrochloride (MDL 72527), sensitized M14 melanoma cells to toxic spermine metabolites (7). MDL 72527 is an inactivator of FAD-dependent polyamine oxidase. It has cytotoxic properties, which are, however, unrelated to its ability to inactivate polyamine oxidase (57). Since MDL 72527 has a different mechanism of toxicity, it could be useful by amplifying cell death induced by $\mathrm{H}_{2} \mathrm{O}_{2}$ and aldehydes (58).

In conclusion, the toxic enzymatic oxidation products generated by BSAO and polyamines could be useful as a combined treatment approach with hyperthermia $\left(39.5-42^{\circ} \mathrm{C}\right)$ or with other drugs, such as lysosomotropic compounds, with the hope of discovering new avenues for eliminating several types of solid tumours, including melanomas and carcinomas, particularly those with MDR phenotypes, in earlier and later stages of disease.

\section{Acknowledgements}

We thank Dr Jacques Jean-Francois, Denis Flipo, Michel Marion, Giampiero Tempera and Alessandro Martone for technical assistance and the Natural Sciences and Engineering Research Council of Canada (Collaborative Health Research Projects Program) (DAB, GF) and the Canadian Institutes for Health Research (DAB) for their financial support. This study was partially supported by Ministero della Sanità (1\% Fondo Sanitario Nazionale), the Italian MIUR (Ministero dell'Istruzione, dell'Università e della Ricerca) and by funds MIUR-PRIN (Cofin) (EA). Thanks are due to the University of Rome 'La Sapienza' for grant support for Professor D. Averill-Bates as visiting Professor in June 2004 to carry out a joint research project supported by NSERC Canada and CIHR.

\section{References}

1. Pegg AE: Polyamine metabolism and its importance in neoplastic growth and a target for chemotherapy. Cancer Res 48: 759-774, 1988.

2. Wallace HM and Fraser AV: Polyamine analogues as anticancer drugs. Biochem Soc Trans 31: 393-396, 2003.

3. Mondovì B, Riccio P, Agostinelli E and Marcozzi G: Oxidation of diamines and polyamines. In: The Physiology of Polyamines. Bachrach U and Heimer YM (eds). Vol. 1. CRC Press, Boca Raton, pp177-201, 1989.

4. Bachrach U: Polyamines as indicators of disease activity and response to therapy in cancer patients. In: The Physiology of Polyamines. Bachrach U and Heimer YM (eds). Vol. 2. CRC Press, Boca Raton, pp234-249, 1989.

5. Lindsay GS and Wallace HM: Changes in polyamine catabolism in HL-60 human promyelogenous leukaemic cells in response to etoposide-induced apoptosis. Biochem J 337: 83-87, 1999.

6. Calcabrini A, Arancia G, Marra M, Crateri P, Befani O, Martone A and Agostinelli E: Enzymatic oxidation products of spermine induce greater cytotoxic effects on human multidrugresistant colon carcinoma cells $(\mathrm{LoVO})$ than on their wild-type counterparts. Int J Cancer 99: 43-52, 2002.

7. Agostinelli E, Belli F, Molinari A, Condello M, Palmigiani P, Dalla Vedova L, Marra M, Seiler N and Arancia G: Toxicity of enzymatic oxidation products of spermine to human melanoma cells (M14): sensitisation by heat and MDL 72527. Biochim Biophys Acta 1763: 1040-1050, 2006.

8. Heby $\mathrm{O}$ and Persson L: Molecular genetics of polyamine synthesis in eukaryotic cells. Trends Biochem Sci 15: 153-158, 1990.

9. Marton LJ and Pegg AE: Polyamines as targets for therapeutic intervention. Annu Rev Pharmacol Toxicol 35: 55-91, 1995.

10. Babbar N and Gerner EW: Polyamines as modifiers of genetic risk factors in human intestinal cancers. Biochem Soc Trans 31: 388-392, 2003.

11. Bachrach U: Polyamines and cancer: minireview article. Amino Acids 26: 307-309, 2004.

12. Seiler N: Thirty years of polyamine-related approaches to cancer therapy. Retrospect and prospect. Part 1. Selective enzyme inhibitors. Curr Drug Targets 4: 537-564, 2003.

13. Seiler N: Thirty years of polyamine-related approaches to cancer therapy. Retrospect and prospect. Part 2. Structural analogues and derivatives. Curr Drug Targets 4: 565-585, 2003. 
14. Toninello A, Pietrangeli P, De Marchi U, Salvi M and Mondov B: Amine oxidases in apoptosis and cancer. Biochim Biophys Acta Rev Cancer 1765: 1-13, 2006.

15. Averill-Bates DA, Cherif A, Agostinelli E, Tanel A and Fortier G: Anti-tumoral effect of native and immobilized bovine serum amine oxidase in a mouse melanoma model. Biochem Pharmacol 69: 1693-1704, 2005.

16. Tabor CW and Tabor H: Polyamines. Annu Rev Biochem 53: 749-790, 1984

17. Tabor CW, Tabor $\mathrm{H}$ and Bachrach $\mathrm{U}$ : Identification of the aminoaldehydes produced by the oxidation of spermine and spermidine with purified plasma amine oxidase. J Biol Chem 239: 2194-2203, 1964.

18. Alarcon RA: Acrolein. IV. Evidence for the formation of the cytotoxic aldehyde acrolein from enzymatically oxidized spermine or spermidine. Arch Biochem Biophys 137: 365-372, 1970.

19. Sharmin S, Sakata K, Kashiwagi K, Ueda S, Iwasaki S, Shirahata A and Igarashi K: Polyamine cytotoxicity in the presence of bovine serum amine oxidase. Biochem Biophys Res Commun 282: 228-235, 2001

20. Averill-Bates DA, Agostinelli E, Przybytkowski E, Mateescu MA and Mondovi B: Cytotoxicity and kinetic analysis of purified bovine serum amine oxidase in the presence of spermine in Chinese hamster ovary cells. Arch Biochem Biophys 300: 75-79, 1993.

21. Agostinelli E, Przybytkowski E and Averill-Bates DA: Glucose, glutathione, and cellular response to spermine oxidation products. Free Rad Biol Med 20: 649-656, 1996.

22. Averill-Bates DA, Agostinelli E, Przybytkowski E and Mondovi B: Aldehyde dehydrogenase and cytotoxicity of purified bovine serum amine oxidase and spermine in Chinese hamster ovary cells. Biochem Cell Biol 72: 36-42, 1994.

23. Lord-Fontaine S, Agostinelli E, Przybytkowski E and Averill-Bates DA: Amine oxidase, spermine, and hyperthermia induce cytotoxicity in P-glycoprotein overexpressing multidrug resistant Chinese hamster ovary cells. Biochem Cell Biol 79: 165-175, 2001.

24. Arancia G, Calcabrini A, Marra M, Crateri P, Artico M, Martone A, Martelli F and Agostinelli E: Mitochondrial alterations induced by serum amine oxidase and spermine on human multidrug resistant tumor cells. Amino Acids 26: 273-282, 2004.

25. Agostinelli E, Belli F, Dalla Vedova L, Marra M, Crateri P and Arancia G: Hyperthermia enhances cytotoxicity of amine oxidase and spermine on drug-resistant LoVo colon adenocarcinoma cells. Int J Oncol 28: 1543-1553, 2006.

26. Robertson JD and Orrenius S: Role of mitochondria in toxic cell death. Toxicology 181-182: 491-496, 2002.

27. Van Engeland M, Nieland LJ, Ramaekers FC, Schutte B and Reutelingsperger CP: Annexin V-affinity assay: a review on an apoptosis detection system based on phosphatidylserine exposure. Cytometry 31: 1-9, 1998.

28. Creagh EM and Martin SJ: Caspases: cellular demolition experts. Biochem Soc Trans 29: 696-702, 2001.

29. Turini P, Sabatini S, Befani O, Chimenti F, Casanova C, Riccio PL and Mondovi B: Purification of bovine plasma amine oxidase. Anal Biochem 125: 294-298, 1982.

30. Janes SM, Mu D, Wemmer D, Smith AJ, Kaur S, Maltby D, Burlingame AL and Klinman JP: A new redox cofactor in eukaryotic enzymes: 6-hydroxydopa at the active site of bovine serum amine oxidase. Science 248: 981-987, 1990.

31. Bates DA and Mackillop WJ: Hyperthermia, adriamycin transport, and cytotoxicity in drug-sensitive and -resistant Chinese hamster ovary cells. Cancer Res 46: 5477-5481, 1986.

32. Tanel A and Averill-Bates DA: The aldehyde acrolein induces apoptosis via activation of the mitochondrial pathway. Biochim Biophys Acta 1743: 255-267, 2005.

33. Lee $Y$ and Shacter E: Bcl-2 does not protect Burkitt's lymphoma cells from oxidant-induced cell death. Blood 89: 4480-4492, 1997.

34. Hampton MB and Orrenius S: Dual regulation of caspase activity by hydrogen peroxide: implications for apoptosis. FEBS Lett 414: 552-556, 1997.

35. Lord-Fontaine S and Averill-Bates DA: Heat shock inactivates cellular antioxidant defenses against hydrogen peroxide: protection by glucose. Free Radic Biol Med 32: 752-765, 2002.
36. Beckman JS, Minor RL, White CW, Repine JE, Rosen GM and Freeman BA: Superoxide dismutase and catalase conjugated to polyethylene glycol increases endothelial enzyme activity and oxidant resistance. J Biol Chem 263: 6884-6892, 1988.

37. Garcia-Calvo M, Peterson EP, Leiting B, Ruel R, Nicholson DW and Thornberry NA: Inhibition of human caspase by peptide-based and macromolecular inhibitors. J Biol Chem 273: 32608-32613, 1998.

38. Parchment RA and Pierce GB: Polyamine oxidation, programmed cell death, and regulation of melanoma in the murine embryonic limb. Cancer Res 49: 6680-6686, 1989.

39. Kroemer G, Dallaporta B and Resche-Rigon M: The mitochondrial death/life regulator in apoptosis and necrosis. Annu Rev Physiol 60: 619-642, 1998.

40. Bonneau MJ and Poulin R: Spermine oxidation leads to necrosis with plasma membrane phosphatidylserine redistribution in mouse leukemia cells. Exp Cell Res 259: 23-34, 2000.

41. Oredsson SM: Polyamine dependence of normal cell-cycle progression. Biochem Soc Trans 31: 366-370, 2003.

42. Wallace HM, Fraser AV and Hughes A: A perspective of polyamine metabolism. Biochem J 376: 1-14, 2003.

43. Kramer DL, Chang BD, Chen Y, Diegelman P, Alm K, Black AR, Roninson IB and Porter CW: Polyamine depletion in human melanoma cells leads to G1 arrest associated with induction of $\mathrm{p} 21^{\mathrm{WAF} / \mathrm{CIP} / \mathrm{SDI} 1}$, changes in the expression of p21-regulated genes, and a senescence-like phenotype. Cancer Res 61: 7754-7762, 2001.

44. Flamigni F, Facchini A, Capanni C, Stefanelli C, Tantini B and Caldarera CM: p44/42 Mitogen-activated protein kinase is involved in the expression of ornithine decarboxylase in leukemia L1210 cells. Biochem J 341: 363-369, 1999.

45. Bachrach U, Wang YC and Tabib A: Polyamines: new cues in cellular signal transduction. News Physiol Sci 16: 106-109, 2001.

46. Seiler N and Raul F: Polyamines and apoptosis. J Cell Mol Med 9: 623-642, 2005.

47. Schipper RG, Penning LC and Verhofstad AA: Involvement of polyamines in apoptosis. Facts and controversies: effectors or protectors? Semin Cancer Biol 10: 55-68, 2000.

48. Stefanelli C, Bonavita F, Stanic I, Mignani M, Facchini A, Pignatti C, Flamigni F and Caldarera CM: Spermine causes caspase activation in leukaemia cells. FEBS Lett 437: 233-236, 1998.

49. Stefanelli C, Bonavita F, Stanic I, Pignatti C, Flamigni F, Guarnieri $\mathrm{C}$ and Caldarera CM: Spermine triggers the activation of caspase-3 in a cell-free model of apoptosis. FEBS Lett 451: 95-98, 1999.

50. Nitta T, Igarashi K and Yamamoto N: Polyamine depletion induces apoptosis through mitochondria-mediated pathway. Exp Cell Res 276: 120-128, 2002.

51. Soengas MS and Lowe SW: Apoptosis and melanoma chemoresistance. Oncogene 22: 3138-3151, 2003.

52. Demers N, Agostinelli E, Averill-Bates DA and Fortier G: Immobilization of native and polyethyleneglycol-treated ('PEGylated') bovine serum amine oxidase into a biocompatible hydrogel. Biotechnol Appl Biochem 33: 201-207, 2001.

53. Agostinelli E, Przybytkowski E, Mondovi B and Averill-Bates DA: Heat enhancement of cytotoxicity induced by oxidation products of spermine in Chinese hamster ovary cells. Biochem Pharmacol 48: 1181-1186, 1994.

54. Van Der Zee J: Heating the patient: a promising approach? Ann Oncol 13: 1173-1184, 2002.

55. Urano M, Kuroda M and Nishimura Y: For the clinical application of thermochemotherapy given at mild temperatures. Int $\mathbf{J}$ Hyperthermia 15: 79-107, 1999.

56. Kochi M, Takeuchi S, Mizutani T, Mochizuki K, Matsumoto Y and Saito Y: Antitumor activity of benzaldehyde. Cancer Treat Rep 64: 21-23, 1980.

57. Seiler N, Duranton B and Raul F: The polyamine oxidase inactivator MDL 72527. Prog Drug Res 59: 1-40, 2002.

58. Agostinelli E, Dalla Vedova L, Belli F, Condello M, Arancia G and Seiler N: Sensitization of human colon adenocarcinoma cells (LoVo) to reactive oxygen species by a lysosomotropic compound. Int J Oncol 29: 947-955, 2006. 